\title{
ZARZĄDZANIE FINANSAMI JEDNOSTEK SAMORZĄDÓW TERYTORIALNYCH W KONTEKŚCIE PANDEMII COVID-19
}

\author{
Żaneta Warzecha ${ }^{1}$, Anna Martynko ${ }^{2}$ \\ 1,2 Politechnika Częstochowska \\ Wydział Zarządzania
}

\begin{abstract}
Streszczenie: We współczesnych realiach turbulentnego otoczenia, niezależnie od sektora, funkcjonowanie podmiotów gospodarczych obwarowane jest licznymi trudnościami. Obecnie w największym stopniu przyczynił się do tego wybuch wirusa SARS-CoV-2. Wstrząs wywołany pandemią COVID-19 uwypuklił wiele problemów gospodarki finansowej jednostek samorządów terytorialnych, narastających na przestrzeni ostatnich dziesięcioleci. Dotychczasowe badania dotyczące problematyki pandemii COVID-19 w głównej mierze odnoszą się do zagadnień prezentowanych $\mathrm{w}$ skali makro. W związku z tym celem niniejszej publikacji jest przybliżenie problematyki związanej z zarządzaniem finansami jednostek samorządów terytorialnych. Na bazie rozważań teoretycznych omówiono aspekty efektywnego zarządzania finansami jednostek samorządów terytorialnych, które mają odzwierciedlenie w zdolności do rozwoju. Z kolei część empiryczna została opracowana przy użyciu metody desk research. Ponadto niniejszy artykuł wzbogacono o wybrane metody statystyczne, tj. metodę TOPSIS oraz metodę Hellwiga. Przeprowadzona analiza wskazuje, iż w największym stopniu skutki pandemii odczuły jednostki samorządów terytorialnych o charakterze turystycznym. Autonomiczność determinowana wysokimi dochodami własnymi w poprzednich latach wpływa negatywnie na obecną sytuację finansową omawianych jednostek samorządów terytorialnych.
\end{abstract}

Słowa kluczowe: jednostki samorząów terytorialnych, metoda TOPSIS, metoda Hellwiga, potencjał finansowy, wskaźniki budżetowe

DOI: 10.17512 /znpcz.2021.3.06

\section{Wprowadzenie}

Obecnie działalność wszystkich podmiotów gospodarujących jest utrudniona, do czego w głównej mierze przyczynił się wybuch wirusa SARS-CoV-2. Narastające na przestrzeni ostatnich dziesięcioleci problemy uwypuklone zostały przez pandemię COVID-19. Większość dotychczasowych badań na temat pandemii COVID-19 poruszała zagadnienia rozpatrywane w skali makro. Czynniki potencjału finansowego i inwestycyjnego jednostek samorządów terytorialnych determinują ich aktywność inwestycyjną. Własny potencjał finansowy określić należy jako wielkość środków pochodzących z uzyskiwanych i transferowych dochodów, które samorząd jest w stanie przekazać w danym okresie na pokrycie wydatków inwestycyjnych. Zamysłem niniejszego opracowania jest poruszenie problematyki zarządzania finansami

\footnotetext{
${ }^{1}$ Żaneta Warzecha, mgr, zaneta.warzecha@pcz.pl, ORCID: 0000-0002-5141-0128

${ }^{2}$ Anna Martynko, mgr, anna.martynko@pcz.pl, ORCID: 0000-0002-9340-9686
} 
jednostek samorządów terytorialnych. Rozważania teoretyczne przedstawiono poprzez omówienie wybranych aspektów gospodarowania finansami samorządów lokalnych, które przekładają się na zdolność do rozwoju. Natomiast część empiryczna stanowi analizę metodą desk research. Co więcej, niniejsze rozważania rozbudowano o wybrane metody statystyczne, między innymi metodę Hellwiga oraz metodę TOPSIS.

\section{Przegląd literatury w obszarze zarządzania finansami samorządów lokalnych}

Budżet jednostki samorządu terytorialnego (JST) jest zarówno narzędziem bieżącego zarządzania jej finansami, jak również zarządzania rozwojem poprzez planowanie i finansowanie inwestycji pokrywanych ze środków publicznych (LukomskaSzarek 2011, s. 75-80). Inwestycje realizowane są na rzecz lokalnej społeczności, która pokrywa te koszty z tytułu opłacanych podatków oraz innych opłat do budżetów samorządowych (Cilak 2018, s. 31-34). Istnieją także czynniki niezależne od władz czy społeczności lokalnych, które mają wpływ na funkcjonowanie jednostek samorządów terytorialnych. Zaliczyć do nich można położenie samorządów względem szlaków osadniczych czy komunikacyjnych bądź wielkość lokalnej bazy ekonomicznej (Sierak 2016, s. 62-64). Widoczne jest, iż zasoby finansowe są istotnym czynnikiem determinującym rozwój jednostki samorządu terytorialnego, natomiast określenie elementów kształtujących te zasoby jest powiązane z ustaleniem czynników kształtujących potencjał finansowy (Kubiczek 2014, s. 40-46).

Pojęcie potencjału jednostek samorządów terytorialnych pojawiające się w literaturze w aspekcie zasobowo-czynnikowym oznacza zbiór zasobów (środowiskowych, rzeczowych i ludzkich), a także wiedzę i kompetencje do ich efektywnego wykorzystania w przyszłości. Potencjał ten nie jest samodzielną kategorią, gdyż na jego poziom mają wpływ czynniki zewnętrzne w postaci otoczenia makro- i mikroekonomicznego oraz czynniki środowiskowe, interpretowane jako czynnik intensyfikujący zrównoważony rozwój (Filipiak, Tarczyńska-Łuniewska 2016, s. 13-18). Sam rozwój określany jest jako pozytywne zmiany ilościowe i jakościowe, bazujące na zastosowaniu możliwych zasobów regionalnych do polepszenia dobrobytu regionu oraz wzmacniania celów równościowych (Standar, Kozera 2019, s. 1-2).

W literaturze obecne są również inne definicje potencjału JST, a jedna $\mathrm{z}$ nich określa potencjał jako połączenie różnych potencjałów cząstkowych, które decydują o jego specyfice, przewadze i zdolnościach do rozwoju (Postuła 2013, s. 82-84). Wyróżnia się zatem potencjał ekonomiczny, gospodarczy i społeczno-gospodarczy, które są pojęciami podobnymi i silnie ze sobą powiązanymi, co sprawia, iż ciężko je od siebie odróżnić. Czynnikiem warunkującym rozwój JST jest przede wszystkim potencjał społeczno-gospodarczy, oparty na trzech składowych potencjałach, takich jak: środowiskowy, ludzki i ekonomiczno-finansowy, które zmieniają się w czasie i poddane są wzajemnym interakcjom. We wszystkich trzech wymienionych potencjałach czynnikiem stymulującym zmiany jest potencjał finansowy, który rzutuje na teraźniejszość, a także wpływa na ich kształtowanie się w przyszłości (Markowski 
2011, s. 13-14). Potencjał finansowy jest rozumiany jako własny potencjał dochodowy, inwestycyjny czy rozwojowy (Miszczuk 2004, s. 67-72). Podejście to zawiera w sobie orientację zasobową oraz równocześnie element czasu i przestrzeni, w której zachodzą procesy. Potencjał finansowy to zatem istniejące zasoby finansowe, potencjalne aktywne możliwości oddziaływania na wzrost zasobów finansowych przez aktywną politykę prowadzoną przez władze samorządowe, a także sposobność pasywnego kreowania zasobów finansowych (Filipiak, Tarczyńska-Łuniewska 2016, s. 13-18).

Do grup czynników kreujących potencjał finansowy zaliczyć można: zasoby finansowe będące aktualnie w posiadaniu JST oraz politykę aktywnego i pasywnego kreowania zasobów finansowych (Brol (red.) 2004, s. 70-75).

Dla kształtowania potencjału finansowego ważne jest określenie oddziaływania pozostałych czynników potencjału JST, z którymi może on być skorelowany. W literaturze, zgodnie z przeprowadzonymi dotychczas badaniami empirycznymi, można wskazać czynniki silnie powiązane $\mathrm{z}$ elementami tworzącymi potencjał finansowy. Do bieżących zasobów finansowych zaliczyć można następujące grupy zmiennych: dochody własne, dochody bieżące, dochody majątkowe, środki UE, pozostałe środki bezzwrotne, nadwyżkę budżetu bieżącego, nadwyżkę budżetową oraz inne specyficzne cechy dla danej jednostki samorządu terytorialnego. Wzrost dochodów własnych i majątkowych stanowi stymulantę potencjału finansowego. Kolejne trzy czynniki mogą stanowić jednocześnie stymulantę i destymulantę potencjału finansowego. Do czynników wchodzących w skład polityki aktywnego kreowania zasobów finansowych należą m.in.: polityka dochodowa, polityka wydatkowa, poziom udzielonej przez jednostki samorząów terytorialnych pomocy publicznej, ulgi i umorzenia, a także inne specyficzne dla danej jednostki cechy. Czynniki składające się na politykę pasywnego kreowania to m.in.: możliwość zaciągania zobowiązań dłużnych, możliwość zaciągania zobowiązań niezaliczanych do długu, obsługa długu, deficyt budżetu bieżącego, deficyt budżetowy i inne. Wszystkie wielkości danych opisujących bieżące zasoby finansowe wykazywane są przez jednostki samorządów terytorialnych w sprawozdaniach budżetowych, jak i różnych sprawozdaniach finansowych oraz raportach. Dane te przyjmuje się do oszacowania potencjału finansowego (Filipiak, Tarczyńska-Łuniewska 2016, s. 13-18). Wszystkie mierniki, poza wskaźnikiem polityki pasywnego kreowania zasobów finansowych, winny być zestawione z aktualną liczbą mieszkańców danej jednostki samorządu terytorialnego. Nie wszystkie jednostki samorządów terytorialnych realizują tę samą i na takim samym poziomie politykę aktywnego i pasywnego kreowania zasobów finansowych. Zatem jednoznaczne stwierdzenie, czy polityka ta będzie stymulantą, czy destymulantą, jest utrudnione (Ziemiańczyk 2010, s. 31-33). Między innymi można wskazać, iż wysoki poziom wydatków inwestycyjnych intensyfikuje poprawę jakości życia mieszkańców, natomiast w dłuższej perspektywie czasowej może prowadzić do zapaści i załamania się tej jakości. Ma to miejsce w momencie, gdy konieczna jest spłata zaciągniętych zobowiązań dłużnych czy uznanych za niekwalifikowane środków z Unii Europejskiej z osiąganych dochodów. W literaturze można odnaleźć liczne argumenty przemawiające za niejednoznaczną 
oceną poszczególnych czynników stymulujących i destymulujących potencjał finansowy w jednostkach samorządów terytorialnych. Najwłaściwsze zatem jest indywidualne rozpatrywanie poszczególnych argumentów kreujących potencjał finansowy w odniesieniu do każdej z badanych instytucji.

Pomiaru potencjału finansowego można dokonywać przy wykorzystaniu analizy jakościowej bądź ilościowej. Elementy ilościowe są kwantyfikowalne i umożliwiają badanie problemu przez pryzmat wielkości liczbowych, a także uznawane są za pomiary obiektywne. Jakościowe podejście natomiast uznawane jest za subiektywne z uwagi na bezpośrednie i pośrednie odczucia osób dokonujących oceny.

\section{Metodyka badań}

Podwalinę badań niniejszego rozważania stanowi zbiór wskaźników opracowany przez Ministerstwo Finansów, na kanwie których sprecyzowano potencjał finansowy wybranych jednostek samorządów terytorialnych. W ramach analizy zostały omówione gminy o typie miejskim, wiejskim oraz jedno miasto na prawach powiatu.

Dobór próby badawczej był nielosowy, podyktowany otrzymanym wsparciem rządowym pod nazwą „Śląski Pakiet dla Turystyki”. Projekt zakładał wsparcie finansowe przeznaczone dla 12 miejscowości turystycznych zlokalizowanych w województwie śląskim (Bielsko-Biała, Jaworze, Wilkowice, Brenna, Istebna, Szczyrk, Ustroń, Wisła, Gilowice, Jeleśnia, Rajcza, Węgierska Górka). Zamysłem programu była pomoc przydzielona $\mathrm{w}$ formie rekompensat, $\mathrm{w}$ związku $\mathrm{z}$ niższymi dochodami budżetowymi, na które znaczny wypływ miały turbulencje w ruchu turystycznym (Śot 2021).

\section{Wskaźniki budżetowe analizowanych samorządów lokalnych}

Na przestrzeni lat 2017-2019 we wszystkich analizowanych JST dochody bieżące stanowiły ponad $90 \%$ dochodów ogółem. Oscylujący na poziomie powyżej $90 \%$ indykator $\mathrm{Wb}_{1}$ ma odzwierciedlenie w niskim udziale dochodów majątkowych generowanych przez posiadane zasoby będące $\mathrm{w}$ dyspozycji omawianych samorządów lokalnych. Wyjątek stanowił rok 2020. Pandemia wpłynęła na regres poziomu dochodów bieżących $\mathrm{w}$ dochodach ogółem. Jednakże minimalna wartość udziału w dalszym ciągu kształtowała się na wysokim poziomie powyżej 70,59\% dochodów bieżących w dochodach ogółem.

Pandemia wywołana wirusem SARS-CoV-2 pogłębiła negatywny trend obniżających się od 2018 roku dochodów własnych, które w analizowanym okresie nie przekroczyły $68,00 \%$. Największe spadki w roku 2020 charakterystyczne dla Szczyrku w poziomie dochodów własnych $\mathrm{w}$ dochodach ogółem oscylują $\mathrm{w}$ granicach około 23,73 p.p. Obserwowany negatywny trend niewysokich dochodów własnych w dochodach ogólem w analizowanych gminach, kształtujący się na średnim poziomie od $42,80 \%$ do $47,64 \%$, ma odzwierciedlenie w niskim poziomie samodzielności finansowej, przekładając się przy tym na stabilność oraz autonomiczność badanych jednostek ze względu na silne uzależnienie się od dochodów transferowych.

Dodatnia wartość wyniku bieżącego, określona jako nadwyżka operacyjna, wskazuje na potencjalne zdolności i możliwości JST do spłaty zobowiązań oraz do 
finansowania wydatków o charakterze inwestycyjnym. Udział nadwyżki operacyjnej i dochodów ze sprzedaży majątku w dochodach ogółem w analizowanych podmiotach pokazuje, iż wszystkie gminy wykazują dodatnią nadwyżkę operacyjną, co można uznać za pozytywny trend. Omawiane jednostki samorządów terytorialnych nie posiadają wysokiego potencjału w zdolności do spłaty zobowiązań oraz finansowania zadań o charakterze inwestycyjnym. $Z$ reguły nadwyżka operacyjna $w$ tych podmiotach w stosunku do dochodów ogółem nie przekracza 17\%. Pandemia, podobnie jak w poprzednich indykatorach, negatywnie wpłynęła na możliwość finansowania zobowiązań oraz wydatków o charakterze inwestycyjnym.

Największe nakłady inwestycyjne badane gminy poczyniły w latach 2018-2019. Najwyższy udział wydatków majątkowych w stosunku do wydatków ogółem obserwuje się w gminie Wilkowice, wynosił on 32,80\% w 2019 roku. Zaś najniższy poziom wydatków majątkowych w wydatkach ogółem typowy jest dla gminy Węgierska Górka - w 2017 roku nie przekroczył 5\%. Wbrew pozorom pandemia nie zatrzymała wszystkich zaplanowanych i rozpoczętych inwestycji, które prawdopodobnie wynikają ze zobowiązań związanych z realizowanymi projektami unijnymi.

We wszystkich analizowanych podmiotach najwyższy udział w wydatkach bieżących stanowiły wydatki na wynagrodzenia i pochodne od nich. W roku 2020 można zauważyć spadek udziału wynagrodzeń i pochodnych od nich w wydatkach bieżących, oscylujący średnio na poziomie około $40 \%$, do czego prawdopodobnie przyczyniła się ograniczona liczba zawieranych umów zleceń.

Analizując wskaźnik $W b_{7}$, można zauważyć, iż w roku 2017 oraz 2019 Szczyrk nie wykorzystał swoich możliwości własnych pokrycia realizowanych inwestycji generowanymi dochodami majątkowymi i nadwyżką operacyjną. W badanych gminach nie wystąpiło ryzyko utraty płynności. $Z$ reguły większość badanych samorządów lokalnych była w stanie w $100 \%$ pokryć wydatki majątkowe dochodami majątkowymi i nadwyżką operacyjną. Wyjątkiem są Bielsko-Biała, Brenna oraz Ustroń. $Z$ czego najniższą zdolność samofinansowania w roku 2020 posiadała gmina Ustroń, której zdolność kształtowała się na poziomie $43 \%$.

Podobnie jak w analizowanych jednostkach, udział dochodów bieżących w dochodach ogółem w latach 2017-2019 kształtował się na średnim poziomie powyżej $91 \%$. Rok 2020 skutkował spadkiem dochodów bieżących w strukturze dochodów ogółem. Jednakże wartość tego indykatora dla gmin ogółem w Polsce kształtuje się na wyższym poziomie niż $\mathrm{w}$ analizowanych samorządach, wynosząc $89,86 \%$ dochodów ogółem. Odmiennie niż w analizowanych gminach miara udziału dochodów własnych dla gmin ogółem w Polsce w latach 2017-2020 nie przekroczyła $44,01 \%$ dochodów własnych w sumie dochodów. Przy czym najwyższy udział dochodów własnych w sumie dochodów charakterystyczny jest dla roku 2020. Należy zauważyć, iż wszystkie analizowane samorządy turystyczne wykazują wyższy poziom autonomiczności niż gminy ogółem w Polsce. Analizowane samorządy lokalne w zestawieniu $\mathrm{z}$ ogółem gmin w Polsce wykazują nieznacznie niższy udział nadwyżki operacyjnej w dochodach ogółem w latach 2018-2019, kształtując się na średnim poziomie nieprzekraczającym $11,06 \%$. Wyjątek stanowią gminy Brenna, Istebna, Gilowice i Rajcza, dla których średnia miara tego wskaźnika w latach 2017-2019 kształtowała się w przedziale 6,93-7,75\%. Nakłady inwestycyjne dla gmin 
ogółem w Polsce nie przekroczyły $20 \%$ wszystkich wydatków w całym analizowanym okresie. Podobna sytuacja klaruje się w analizowanych samorządach lokalnych w latach 2017-2019, w których średni poziom wydatków inwestycyjnych zawiera się w przedziale 10,53-19,25\%. W roku 2020 wskaźnik udziału wydatków majątkowych w sumie wydatków dla gmin ogółem w Polsce kształtował się na poziomie około $14,82 \%$, co stanowi zbliżoną wartość dla analizowanych podmiotów. Wyjątkiem są dwie gminy, dla których miara wydatków majątkowych w ogóle wydatków jest wyższa - o około 15,88 p.p. dla Wilkowic oraz 7,20 p.p. dla Istebnej. Samorządy lokalne w omawianym okresie generują wyższe wydatki na wynagrodzenia i pochodne od nich w ogóle wydatków bieżących niż średnia dla gmin w Polsce o około 2 p.p. Wyjątkiem jest rok 2020, w którym udział wydatków na wynagrodzenia i pochodne od nich jest wyższy dla średniej ogółem w Polsce o około 1 p.p. W latach 2017-2020 analizowane beskidzkie miejscowości turystyczne wykazują wyższy udział nadwyżki operacyjnej i dochodów ze sprzedaży majątku w strukturze dochodów. Dla gmin ogółem w Polsce wspomniana miara nie przekracza $10,1 \% \mathrm{w}$ roku 2017, zaś na przestrzeni kolejnych lat obserwuje się trend spadku omawianego indykatora do poziomu 9,62\% w 2020 roku. Biorąc pod uwagę wskaźnik samofinansowania, można zauważyć, iż udział nadwyżki operacyjnej i dochodów majątkowych w wydatkach majątkowych w pierwszym $\mathrm{z}$ analizowanych lat jest dużo wyższy dla gmin ogółem w Polsce, gdzie miara wspominanego wskaźnika kształtuje się na poziomie $550,80 \%$, co jest około 4 razy wyższym wynikiem niż w 12 omawianych podmiotach. Wyjątek stanowi Szczyrk, który generuje wskaźnik finasowania na poziomie $756,10 \%$. Na przestrzeni kolejnych lat można zauważyć, iż analizowane samorządy turystyczne cechują się niższym wskaźnikiem samofinansowania niż gminy ogółem w Polsce. Z kolei w roku pandemicznym można zaobserwować, iż omawiane samorządy lokalne generują wskaźnik samofinansowania na średnim poziomie $117,29 \%$, co przekłada się na niższy wynik niż w gminach ogółem w Polsce, który wynosi około $516,88 \%$; to zaś świadczy o niewykorzystanym potencjale do finansowania nakładów inwestycyjnych w stosunku do posiadanych możliwości.

\section{Wskaźniki budżetowe - metoda TOPSIS}

W artykule opracowano rankingi poszczególnych badanych jednostek samorządów terytorialnych $\mathrm{w}$ latach 2017-2020 przy wykorzystaniu metody TOPSIS. W literaturze polskiej metoda TOPSIS jest klasyfikowana do podstawowych metod wzorcowych porządkowania liniowego obiektów wielocechowych. W rezultacie dąży się do określenia wskaźnika syntetycznego, który tworzy ranking badanych obiektów lub cech (Kobryń, Prystrom 2016).

Rankingi miały na celu porównanie działalności jednostek z punktu widzenia przyjętych wskaźników budżetowych. Każdemu ze wskaźników przydzielono odpowiednią wagę, którą wyliczono przy użyciu współczynników zmienności.

Analizując omówione wyżej indykatory przy użyciu metody TOPSIS, można zauważyć, iż w badanym okresie, tj. w latach 2017-2020, najwyższe miejsca w rankingu zajmowały odpowiednio takie gminy jak: Szczyrk (2017), Jaworze (2018), Węgierska Górka (2019) oraz Wilkowice (2020). Natomiast analogicznie najgorsze 
lokaty typowe są w tym okresie dla gmin: Węgierska Górka, Gilowice oraz Szczyrk. Na najgorszą klasyfikację wpływ miał niski udział dochodów własnych w analizowanych latach. Sytuacja finansowa Szczyrku i Ustronia badana za pomocą wskaźników budżetowych uległa najsilniejszemu pogorszeniu, gdyż z miejsc początkowych spadły w roku 2020 na miejsca końcowe. Największe zauważalne wzrosty w klasyfikacji widoczne są natomiast wśród gmin: Wilkowice, Istebna, Rajcza, Jeleśnia i Gilowice, zwłaszcza w przypadku ostatniej z wymienionych jednostek samorządów terytorialnych, która zajmując w latach 2018 i 2019 ostatnią pozycję, awansowała na miejsce piąte. Względnie stabilną pozycję zajmują Bielsko-Biała, Brenna, a także Wisła.

Reasumując, należy zaznaczyć, iż rok 2020 i trwająca pandemia COVID-19 miały największy wpływ na istotne $\mathrm{i}$ obserwowane zmiany zajmowanych miejsc przez badane jednostki. Odnotowywane są zarówno znaczne spadki klasyfikacyjne, jak również wzrosty.

Tabela 1. Ranking badanych JST ze względu na poziom wskaźników budżetowych wyliczony metodą TOPSIS (lata 2017-2020)

\begin{tabular}{|l|c|c|c|c|}
\hline \multicolumn{1}{|c|}{ Nazwa JST } & $\mathbf{2 0 1 7}$ & $\mathbf{2 0 1 8}$ & $\mathbf{2 0 1 9}$ & $\mathbf{2 0 2 0}$ \\
\hline BIELSKO-BIAŁA & 3 & 5 & 5 & 7 \\
\hline JAWORZE & 7 & 1 & 11 & 6 \\
\hline WILKOWICE & 4 & 3 & 2 & 1 \\
\hline BRENNA & 5 & 9 & 9 & 10 \\
\hline ISTEBNA & 10 & 7 & 7 & 2 \\
\hline SZCZYRK & 1 & 4 & 3 & 12 \\
\hline USTRON & 2 & 2 & 6 & 11 \\
\hline WISŁA & 6 & 6 & 4 & 9 \\
\hline GILOWICE & 9 & 12 & 12 & 5 \\
\hline JELEŚNIA & 11 & 10 & 8 & 4 \\
\hline RAJCZA & 8 & 11 & 10 & 3 \\
\hline WEGIERSKA GÓRKA & 12 & 8 & 1 & 8 \\
\hline
\end{tabular}

Źródło: Opracowanie własne na podstawie danych Ministerstwa Finansów (https://www.gov.pl/...) oraz sprawozdania $\mathrm{z}$ wykonania budżetu omawianych jednostek samorządów terytorialnych (https://www.bip.gov.pl)

W związku z trudną sytuacją finansową w roku 2020 analizowane samorządy lokalne z reguły zwiększały poziom swojego zadłużenia. Najwyższy poziom zobowiązań w dochodach ogółem w roku 2020 typowy jest dla gminy Brenna. Obciążenie dochodów zobowiązaniami kształtuje się na średnim poziomie 52,55\%. Zaś najniższy poziom udziału zobowiązań w dochodach ogółem charakterystyczny jest dla gminy Szczyrk, która sukcesywnie zmniejszała poziom swoich zobowiązań w sumie dochodów ogółem. Poziom tego indykatora w 2020 roku kształtował się w granicach $1,40 \%$. Omawiane podmioty nie posiadały zobowiązań wymagalnych. Wszystkie gminy terminowo dokonywały spłat swoich zobowiązań. 


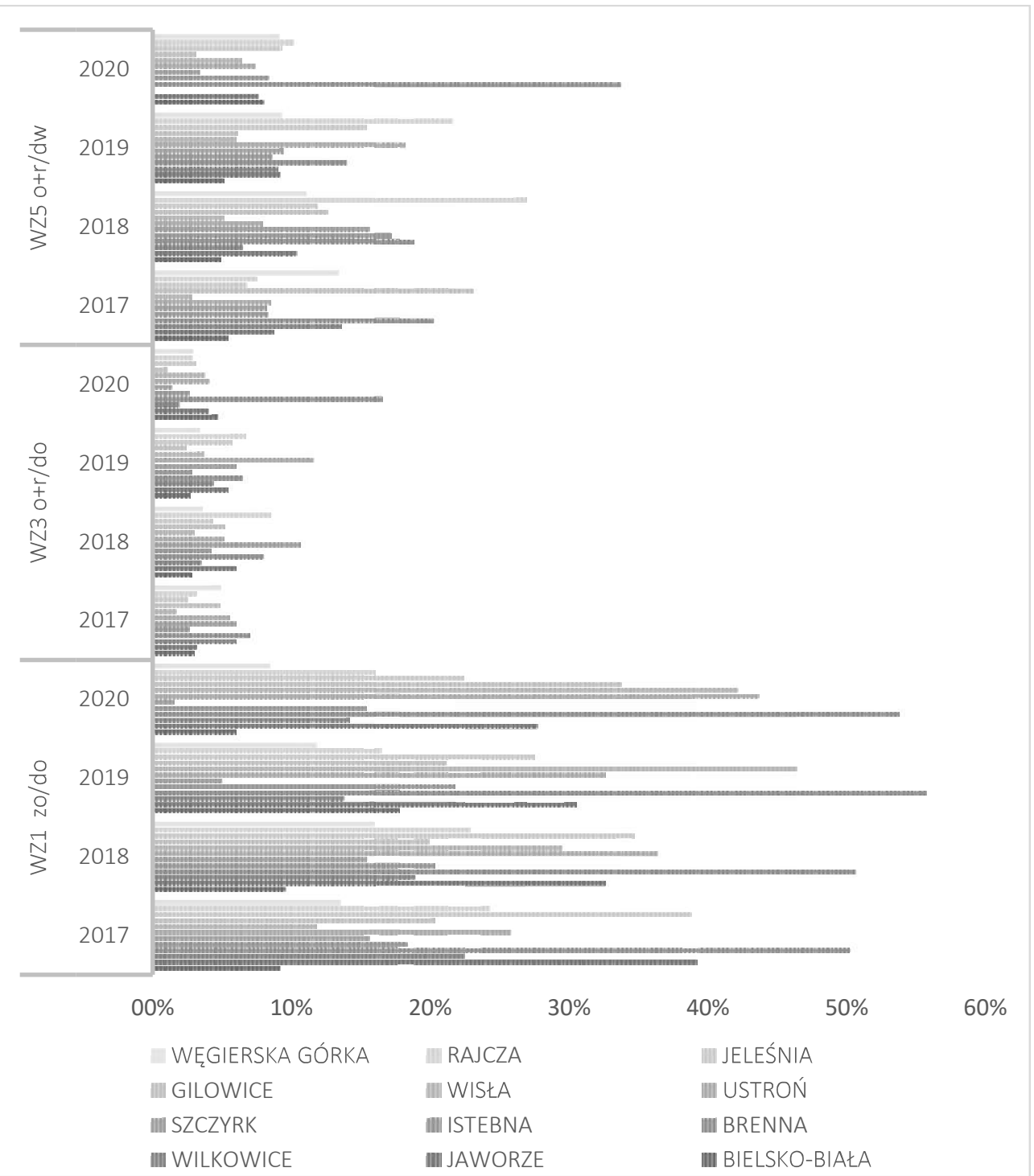

Rysunek 1.Wskaźniki budżetowe według tytułów dłużnych w latach 2017-2020

Źródło: Opracowanie własne na podstawie danych Ministerstwa Finansów (https://www.gov.pl/...) oraz sprawozdania $\mathrm{z}$ wykonania budżetu omawianych jednostek samorządów terytorialnych (https://www.bip.gov.pl)

\section{Wskaźniki budżetowe na mieszkańca - metoda Hellwiga}

Ostatnim elementem oceny sytuacji finansowej jednostek samorządów terytorialnych podawanym przez Ministerstwo Finansów jest ocena atrakcyjności samorządów lokalnych, które omówiono przy wykorzystaniu metody Hellwiga, dla których optymalny zbiór zmiennych stanowi kombinację $C 4=\left(X_{1}, X_{2}\right)$. 
gdzie:

$X_{1}$ - wskaźnik $W_{L 1}$

$X_{2}$ - wskaźnik $W_{L 2}$

Natomiast otrzymany model przedstawia się następująco:

gdzie:

$$
Y=a_{0}+a_{1} X_{1}+a_{2} X_{2}+\varepsilon
$$

$Y$ - zmienna zależna, skutek, zmienna objaśniana, endogeniczna

$a_{0}$ - oszacowana wartość wyrazu wolnego, estymator

$a_{i}$ - oszacowane wartości współczynników regresji

$X_{i}$ - zmienne objaśniajace

$\varepsilon$-składnik losowy, reprezentujący rozrzut punktów wokół płaszczyzny regresji

Analizując wskaźniki na mieszkańca, można zauważyć, iż na przestrzeni badanych lat kwota dochodów przypadających na jednego mieszkańca kształtowała się na średnim poziomie od 2238,09 zł do 3164,06 zł. Pandemia przyczyniła się do zwiększenia wielkości transferów bieżących na mieszkańca. Było to spowodowane wzrostem udzielonych dotacji na walkę $\mathrm{z}$ negatywnymi skutkami pandemii COVID-19, czego przykładem może być program „Śląskie Pomaga”. Jednakże przyczyn tego zjawiska można doszukiwać się również $\mathbf{w}$ zwiększonym odsetku śmiertelności spowodowanym obecną sytuacją pandemiczną.

$Z$ kolei nadwyżka operacyjna netto na przestrzeni badanego okresu nie przekracza 850,00 zł na mieszkańca. W latach 2017-2020 najniższy pułap bezpieczeństwa finansowego odnotowuje gmina Wilkowice, dla której nadwyżka operacyjna per capita kształtuje się w przedziale od 302,58 zł do 163,87 zł. Natomiast w najmniejszym stopniu na ryzyko utraty płynności narażone jest Bielsko-Biała, dla którego omawiany indykator kształtuje się na średnim poziomie 598,51 zł, co może wynikać ze specyfiki badanego podmiotu jako miasta na prawach powiatu. Wysoki poziom nadwyżki operacyjnej w latach 2017-2019 w przeliczeniu na mieszkańca charakterystyczny jest dla Ustronia, jednakże pandemia COVID-19, wpłynęła na obniżenie tejże miary o około $382,79 \mathrm{zł}$ w stosunku do wcześniejszego roku.

\section{Operacyjna całkowita zdolność do rozwoju oraz indywidualny wskaźnik zadłużenia}

Niniejsze rozważania na temat potencjału finansowego badanych samorządów lokalnych uzupełniono o zdolność do rozwoju oraz o indywidualny wskaźnik zadłużenia.

Syntetycznej oceny potencjału rozwojowego, wskazującego na ewentualne możliwości finansowania nakładów inwestycyjnych danego samorządu lokalnego, dokonano przy wykorzystaniu miar jakościowych. Analizę potencjału rozwojowego omówiono na podstawie dwóch wskaźników: operacyjnej oraz całkowitej zdolności do rozwoju wybranych samorządów lokalnych. 


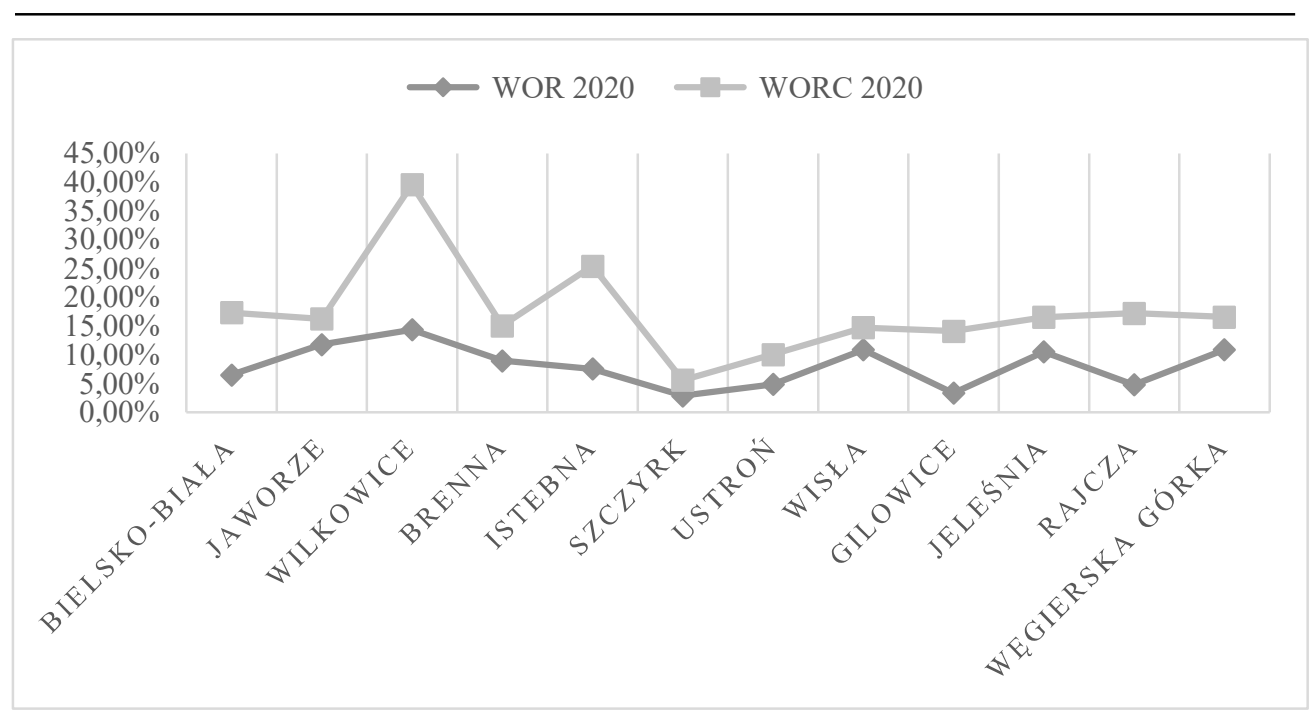

Rysunek 2. Operacyjna i całkowita zdolność do rozwoju wybranych samorządów lokalnych w roku 2020 (\%)

Źródło: Opracowanie własne na podstawie danych Ministerstwa Finansów (https://www.gov.pl/...) oraz sprawozdania $\mathrm{z}$ wykonania budżetu omawianych jednostek samorządów terytorialnych (https://www.bip.gov.pl)

Dane zawarte na Rysunku 2 wskazują, iż najwyższym stosunkiem nadwyżki operacyjnej do dochodów bieżących (14,35\%) charakteryzuje się gmina Wilkowice. Zaś najniższe wydatki eksploatacyjne typowe są dla Szczyrku, oscylują one na poziomie $2,85 \%$.

Analiza całkowitej zdolności do rozwoju dowodzi, iż najwyższy udział nadwyżki operacyjnej powiększonej o dochody z prywatyzacji mienia posiada gmina Wilkowice. Podobnie jak w przypadku zdolności operacyjnej w roku 2020 najniższy potencjał finansowania nakładów rozwojowych na poziomie $5,55 \%$ posiada Szczyrk.

Biorąc pod uwagę indywidualny wskaźnik zadłużenia, można zauważyć, że na przestrzeni analizowanych lat 2017-2020 badana miara charakteryzuje się trendem spadku. Indywidualny wskaźnik zadłużenia w analizowanych samorządach lokalnych w latach 2017-2020 nie przekracza 19\%. Największe możliwości w kontekście zaciągania nowych zobowiązań w roku 2019 posiadał Szczyrk, którego indywidualny wskaźnik zadłużenia kształtował się w granicach $18,5 \%$. Na zbliżonym poziomie wartość omawianego indykatora kształtowała się w gminie Wilkowice 17,73\%. Najniższy indywidualny wskaźnik zadłużenia w roku 2019 charakterystyczny jest dla Gilowic oraz Węgierskiej Górki, wynosząc odpowiednio 6,67\% i 7,60\%. W analizowanych jednostkach samorządów terytorialnych pandemia negatywnie wpłynęła na zdolność do zadłużenia. W roku 2020 najmniej środków na obsługę zadłużenia przeznaczały Gilowice $(5,03 \%)$ oraz Istebna $(8,23 \%)$. Największą zdolność do zaciągania zobowiązań posiadały Wilkowice, które na obsługę długu mogły przeznaczyć średnio $11,98 \%$. Na niemal identycznym poziomie omawiany indykator kształtował się w Jaworzu, wynosząc 11,68\%, co przedstawiono na Rysunku 3. 


\begin{tabular}{|c|}
\hline BIELSKO-BIAtA \\
\hline IWZ $2019=\left[1 / 3\left(W_{6} 19+W_{6} 18+W_{6} 17\right)\right]=10,77 \% \quad$ IWZ $2020=\left[1 / 3\left(W_{6} 20+W B_{6} 19+W B_{6} 18\right)\right]=9,17 \%$ \\
\hline JAWORZE \\
\hline IWZ $2019=\left[1 / 3\left(W_{6} 19+W_{6} 18+W B_{6} 17\right)\right]=11,13 \% \quad I W Z 2020=\left[1 / 3\left(W B_{6} 20+W B_{6} 19+W B_{6} 18\right)\right]=11,68 \%$ \\
\hline WILKOWICE \\
\hline IWZ $2019=\left[1 / 3\left(W_{6} 19+W_{6} 18+W_{6} 17\right)\right]=17,73 \% \quad I W Z 2020=\left[1 / 3\left(W B_{6} 20+W B_{6} 19+W B_{6} 18\right)\right]=11,98 \%$ \\
\hline \\
\hline BRENNA \\
\hline IWZ $2019=\left[1 / 3\left(W^{6} B_{6} 19+W_{6} 18+W B_{6} 17\right)\right]=8,67 \% \quad I W Z 2020=\left[1 / 3\left(W B_{6} 20+W B_{6} 19+W B_{6} 18\right)\right]=7,91 \%$ \\
\hline \\
\hline ISTEBNA \\
\hline IWZ 2019 $=\left[1 / 3\left(W_{6} 19+W_{6} 18+W_{6} 17\right)\right]=8,77 \% \quad I W Z 2020=\left[1 / 3\left(W B_{6} 20+W B_{6} 19+W B_{6} 18\right)\right]=8,23 \%$ \\
\hline \\
\hline 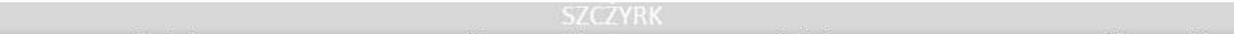 \\
\hline IWZ 2019=[1/3(WB $\left.\left.{ }_{6} 19+W^{6} 18+W_{B} 17\right)\right]=18,50 \% \quad I W Z 2020=\left[1 / 3\left(W B_{6} 20+W B_{6} 19+W B_{6} 18\right)\right]=8,73 \%$ \\
\hline$v^{2}$ \\
\hline USTRON \\
\hline IWZ 2019=[1/3(WB $\left.\left.19+W_{6} 18+W_{6} 17\right)\right]=13,40 \% \quad$ IWZ $2020=\left[1 / 3\left(W B_{6} 20+W B_{6} 19+W B_{6} 18\right)\right]=9,47 \%$ \\
\hline$v^{2}$ \\
\hline WISEA \\
\hline IWZ $2019=\left[1 / 3\left(W_{6} 19+W_{6} 18+W_{6} 17\right)\right]=10,80 \% \quad$ IWZ $2020=\left[1 / 3\left(W B_{6} 20+W B_{6} 19+W B_{6} 18\right)\right]=10,60 \%$ \\
\hline GILOWICE \\
\hline IWZ $2019=\left[1 / 3\left(W_{B} 19+W_{B} 18+W_{6} 17\right)\right]=6,67 \% \quad$ IWZ $2020=\left[1 / 3\left(W_{B} 20+W B_{6} 19+W B_{6} 18\right)\right]=5,03 \%$ \\
\hline JELESNIA \\
\hline IWZ $2019=\left[1 / 3\left(W_{6} 19+W_{B} 18+W B_{6} 17\right)\right]=8,63 \% \quad$ IWZ $2020=\left[1 / 3\left(W_{6} 20+W B_{6} 19+W B_{6} 18\right)\right]=10,25 \%$ \\
\hline RAJCZA \\
\hline IWZ $2019=\left[1 / 3\left(W_{B} 19+W_{B} 18+W_{6} 17\right)\right]=7,97 \% \quad$ IWZ $2020=\left[1 / 3\left(W_{6} 20+W B_{6} 19+W B_{6} 18\right)\right]=6,17 \%$ \\
\hline WËGIERSKA GORKA \\
\hline IWZ $2019=\left[1 / 3\left(W_{6} 19+W_{B} 18+W_{6} 17\right)\right]=7,60 \% \quad$ IWZ $2020=\left[1 / 3\left(W B_{6} 20+W B_{6} 19+W B_{6} 18\right)\right]=10,16 \%$ \\
\hline
\end{tabular}

\section{Rysunek 3. Indywidualny wskaźnik zadłużenia w latach 2017-2020}

Źródło: Opracowanie własne na podstawie danych Ministerstwa Finansów (https://www.gov.p1/...) oraz sprawozdania z wykonania budżetu omawianych jednostek samorząów terytorialnych (https://www.bip.gov.pl)

\section{Podsumowanie}

Można przyjąć, iż zasadniczy cel artykułu, czyli omówienie problematyki dotyczącej zarządzania potencjałem finansowym jednostek samorządów terytorialnych, został zrealizowany. W pracy dokonano przeglądu literaturowego odnoszącego się do wskazania teoretycznych zagadnień dotyczących potencjału finansowego, a także dokonano identyfikacji czynników wchodzących w jego skład. Na podstawie udostępnionych przez badane jednostki samorządów terytorialnych danych liczbowych dokonano rankingu tych podmiotów ze względu na poziom wskaźników budżetowych osiągniętych w latach 2017-2020. Uszeregowania dokonano przy wykorzystaniu metod statystycznych. Przeprowadzona analiza wskazuje, iż pandemia wywołana wirusem SARS-CoV-2 miała negatywny wpływ na jednostki samorządów terytorialnych. W największym stopniu skutki pandemii odczuły jednostki samorządów terytorialnych o charakterze turystycznym. Pandemia COVID-19 w znacznym 
stopniu wpłynęła na potencjał finansowy analizowanych jednostek, który przekłada się na dalsze zdolności rozwojowe omawianych samorządów lokalnych. $Z$ uwagi na wyższą niż dla gmin ogółem w Polsce autonomiczność determinowaną dochodami własnymi omawiane jednostki samorządów terytorialnych zmagają się $\mathrm{z}$ trudną sytuacją finansową w trakcie pandemii, której skutki widać w obecnie realizowanej gospodarce budżetowej poszczególnych samorządów. Zasadne zatem wydaje się przeprowadzenie kolejnych badań w kierunku dalszych skutków pandemii COVID-19 na funkcjonowanie samorządów lokalnych w Polsce.

\section{Literatura}

1. Brol R. (red.) (2004), Ekonomika i zarzadzanie miastem, Wydawnictwo Akademii Ekonomicznej, Wrocław. DOI: 10.12775/CJFA.2018.018.

2. Cilak M. (2018), Financial Stability of Local Government Units - Legal and Economic Approach, „Copernican Journal of Finance \& Accounting”, Vol. 7(4).

3. Filipiak B., Tarczyńska-Łuniewska M. (2016), Potencjat jednostki samorzqdu terytorialnego próba systematyzacji pojęciowej i metodycznej, „Finanse Komunalne”, nr 1/2. DOI: 10.1515/ foli-2016-0036.

4. https://www.bip.gov.pl (dostep: 30.06.2021).

5. https://www.gov.pl/web/finanse/komunikaty-i-opracowania. DOI: 10.7206/mba.ce.20843356.60 (dostęp: 29.06.2020).

6. Kobryń A., Prystrom J. (2016), A Data Pre-Processing Model for the TOPSIS Method, „Folia Oeconomica Stetinensia", Vol. 16(2).

7. Kubiczek A. (2014), Jak mierzyć dziś rozwój społeczno-gospodarczy krajów?, „Nierówności Społeczne a Wzrost Gospodarczy", nr 38(2).

8. Łukomska-Szarek J. (2011), Finansowanie działalności rozwojowej samorzadów terytorialnych, „Zeszyty Naukowe Politechniki Śląskiej”, nr 1864.

9. Markowski K. (2011), Potencjat ekonomiczny miast $w$ województwie lubelskim $w$ latach 2000-2010, Główny Urząd Statystyczny, Lublin.

10. Miszczuk M. (2004), Czynniki różnicujace potencjał finansowy gmin - próba typologii na przykladzie województwa lubelskiego, „Prace Naukowe Uniwersytetu Ekonomicznego we Wrocławiu", nr 46.

11. Postuła M. (2013), Ocena sprawności działania państwa w odniesieniu do skali wydatków publicznych, „Management and Business Administration. Central Europe”, Vol. 21, No. 2(121). DOI: 10.3390/su11205848.

12. Sierak J. (2016), The Role of Local Government in the Process of Stimulating the Development of the Local Economy, ,Journal of Management and Financial Sciences”, Vol. 25.

13. Standar A., Kozera A. (2019), The Role of Local Finance in Overcoming Socioeconomic Inequalities in Polish Rural Areas, „Special Issue Sustainable Value Management - New Concepts and Contemporary Trends", Vol. 11(20).

14. Śot N. (2021), Ślaski Pakiet dla Turystyki - wsparcie dla gmin turystycznych oraz wsparcie MŚP z branży turystycznej, Śląskie. Informacja Turystyczna Województwa Śląskiego, https://www.slaskie.travel/news/1020082/slaski-pakiet-dla-turystyki-wsparcie-dla-gmin -turystycznych-oraz-wsparcie-msp-z-branzy-turystycznej?fbclid=IwAR3e15BP1QRdJjGRg Nw7Ogf0dDdf-yEH45B8Zry8-SCizLUu1PhmD004xfA (dostęp: 30.06.2021).

15. Ziemiańczyk U. (2010), Ocena poziomu rozwoju społeczno-gospodarczego gmin wiejskich i miejsko-wiejskich w województwie małopolskim, „Infrastruktura i Ekologia Terenów Wiejskich", nr 14. 


\title{
FINANCIAL MANAGEMENT OF LOCAL GOVERNMENT UNITS IN CONTEXT
} OF COVID-19 PANDEMIC

\begin{abstract}
In the contemporary reality of a turbulent environment, the functioning of business entities is subject to numerous difficulties, regardless of the sector. Currently, the major contributor to this is the SARS-CoV-2 virus outbreak. The shock caused by the COVID-19 pandemic has highlighted many problems in the financial management of local government units that have been growing over the past decades. The studies conducted to date on the COVID-19 pandemic mainly relate to issues presented on a macro scale. Therefore, the aim of this publication is to present the issues related to the financial management of local government units. On the basis of theoretical considerations, the aspects of effective financial management of local government units, which are reflected in the ability to develop, are discussed. In turn, the empirical part was developed using the desk research method. In addition, this article was enriched with selected statistical methods, i.e. the TOPSIS method and the Hellwig method. The conducted analysis shows that the effects of the pandemic were felt to the greatest extent by local government units of a tourist nature. Autonomy determined by high own incomes in previous years negatively influences the current financial situation of the discussed local government units.
\end{abstract}

Keywords: local government units, TOPSIS method, Hellwig method, financial potential, budget indicators 